\title{
Fair Game? James Joyce, Sean O'Casey, and the Contesting of Irish Sport
}

\section{Dermot Ryan}

\section{Q OpenEdition \\ 1 Journals}

\section{Electronic version}

URL: http://journals.openedition.org/etudesirlandaises/3016

DOI: 10.4000/etudesirlandaises.3016

ISSN: 2259-8863

\section{Publisher}

Presses universitaires de Rennes

\section{Printed version}

Date of publication: 30 June 2012

Number of pages: 105-145

ISSN: 0183-973X

\section{Electronic reference}

Dermot Ryan, «Fair Game? James Joyce, Sean O'Casey, and the Contesting of Irish Sport », Études irlandaises [Online], 37-1 | 2012, Online since 30 June 2014, connection on 01 May 2019. URL : http:// journals.openedition.org/etudesirlandaises/3016 ; DOI : 10.4000/etudesirlandaises.3016 


\title{
Fair Game? James Joyce, Sean O’Casey, and the Contesting of Irish Sport
}

\author{
Dermot Ryan \\ Loyola Marymount University
}

\begin{abstract}
The revival of Gaelic games should be situated in the larger context of the codification of team sports across Great Britain. English schoolboy literature promoted codified sport as a means of forming class alliances, of asserting national identity, and of instilling the martial values needed to govern Britain's growing empire. Irish literature written in support of the revival of Gaelic games explicitly appropriates this martial language, adapting it for anti-colonial and nationalist purposes. The work of James Joyce and Sean O'Casey contests the reappearance in Irish sport of the very chauvinism, militarism, and class sectarianism that had characterized the promotion of codified sport in England.

Keywords: English sport, Gaelic games, schoolboy literature, James Joyce, Sean O'Casey

\section{Résumé}

Il faut situer la renaissance des sports gaéliques dans le contexte plus large de la codification des sports collectifs en Grande-Bretagne. Les livres pour écoliers anglais encourageaient le sport codifié comme moyen de former des alliances de classe, d'affirmer une identité nationale, et de propager les valeurs guerrières nécessaires à l'expansion de l'empire britannique. Les ouvrages irlandais destinés à promouvoir la renaissance des jeux gaéliques adoptent de façon explicite ce langage martial, en l'adaptant à des fins nationalistes et d'anticolonialisme. L'oeuvre de James Joyce et celle de Sean O'Casey contestent la réapparition du même chauvinisme, militarisme et sectarisme de classe qui avaient caractérisé la promotion du sport codifié en Angleterre.
\end{abstract}

Mots clé: Sport anglais, jeux gaéliques, livres pour enfants, James Joyce, Sean O'Casey 
"Nor should the lighter, but still more important question of the sports of the people be forgotten."

George Bernard Shaw, John Bull's Other Island

\section{I}

Daniel Corkery's essay Synge and Anglo-Irish Literature (1931) is an attempt to purge national culture in the newly formed Free State of any influences that could be construed as originating from Great Britain. Corkery's canon excludes many of Ireland's most prominent writers, including Yeats and Joyce, because their work fails to represent those forces that distinguish the Irish national being from its English counterpart. Unlike his English contemporary F.R. Leavis, however, Corkery's vision of a national culture is, at least nominally, populist rather than elitist. Signaling his essential egalitarianism, Corkery opens his study by evoking a place where every type of Irish person gathers. He invokes a crowd, which comprehends the diversity of Irish life, but a crowd whose struggles have not been represented in the work of those Anglo-Irish authors he wishes to exclude from the canon of Irish letters. Corkery describes a Gaelic Athletic Association (G.A.A.) hurling match.

Surveying the 30,000 spectators that have gathered in Tipperary, Corkery sees them as "typical of this nation as any of the great crowds that assemble on Saturday afternoons in England to witness Association football matches are typical of the English nation ${ }^{1 "}$. And yet, Corkery laments, "the life of this people I looked upon - there were all sorts of individuals present from bishops to tramps off the road - was not being explored in a natural way by any except one or two writers of any standing ${ }^{2 \prime}$.

Commentating on Eurovision winner Dana's candidacy for the 1997 Irish presidential election, the journalist Fintan O'Toole presents a radically different reading of the relationship between hurling and the life of the Irish people. O'Toole cites Dana's 1970 victory in the Eurovision as the last moment when the forces of Irish conservatism could imagine "television, Europe, technology and pop culture, might not, after all, be a threat to the old order of Church and state $^{3 "}$ ". He witheringly dismisses the Right's nostalgic vision of Ireland: "The Ireland that the Catholic Right dreams of never existed outside the pages of Knocknagow. And its pale imitations: curly ham sandwiches on the sideline of the hurling pitch, cycling to sodality, Cidona at the ceili have long faded to nothin-

1. Daniel Corkery, Synge and Anglo-Irish Literature, Cork, Cork University Press, 1931, p. 12.

2. Ibid.

3. Fintan O’Toole, "Dreams of the Catholic Right Rest on Dana", Irish Times, 5 August 1997, p. 14. 
gness ${ }^{4}$." In contrast to Corkery, O’Toole describes an Irish identity first formulated in literature (Charles Kickham's Knocknagow), then aped on the hurling pitch, and now threatened by the forces of modernization and popular culture. While Corkery argues that the hurling crowd's representative nature demands expression by a national literature, O'Toole suggests that the Ireland represented by the hurling match is little more than a literary fiction.

This paper will have occasion to challenge the assumptions behind Corkery and O'Toole's arguments. It will consider, for instance, whether the hurling crowd invoked by Corkery was truly typical of the Irish nation. This paper will question O'Toole's neat opposition of the forces of traditionalism and modernization, asking whether native traditions like hurling could have established themselves so securely in post-independence Ireland without the use of modern technologies. But for the moment, I want to draw attention to the way both writers deploy the hurling match as a kind of synecdoche: this discrete gathering expresses a larger national identity. Both writers situate this Irish game at the heart of their discussion of Irish identity.

Yet, for the most part, Irish historians have been reluctant to grant the G.A.A. anything like the importance of the Gaelic League or the Abbey Theatre in the shaping and expression of Irish cultural identity. F.S.L. Lyons's observation that "revolutions are made with ideas, not hurley sticks" and his attendant claim that the Gaelic League was the most significant factor influencing the rise of "the new and urgent sense of nationality at the end of the nineteenth century" is representative of a general tendency to downplay the significance of sport in the politics of cultural nationalism ${ }^{5}$.

While historians have been skeptical of the importance of the G.A.A.'s contribution to cultural nationalism, the literary representation of Irish sport in the immediate wake of the association's foundation suggests that, from the outset, Irish writers recognized Gaelic games as a crucial vehicle of identity formation. From the G.A.A.'s foundation in 1884, writers represented sport, not as an innocent leisure activity, but as a site of intense cultural and political contestation. Indeed, I will argue that writers like James Joyce and Sean O'Casey reveal the G.A.A. as more thoroughly embodying the character of an emergent official nationalism than either the Abbey or the Gaelic League.

This essay will situate the G.A.A.'s emergence in the historical context of the codification of team sports across Great Britain and explore the ways in which school-boy literature celebrated the culture of team sports, promoting them as a

4. Ibid.

5. F. S. L. Lyons, Ireland Since the Famine, London, Fortuna Arts, 1992, p. 227. W.F. Mandle, Conor Cruise O'Brien, and more recently, John Sugden and Alan Bairner are notable exceptions to this tendency to dismiss the political importance of the G.A.A. 
means of forming class alliances, of asserting national identity, and of instilling in England's sons the martial and imperial values needed to govern Britain's growing empire. I will then show how literature written in support of the revival of Irish sport explicitly appropriates the martial language associated with English games and adapts it for anti-colonial and nationalist purposes. Finally, I will argue that the work of Joyce and O'Casey contests the reappearance in Irish sport of the very chauvinism, militarism, and class sectarianism that had characterized the promotion of codified sport in England.

\section{II}

Irish criticism is indebted to authors like Eamonn Hughes and William McCormack whose scholarship interrogates the basic concepts and historical narratives used to understand Irish literature and culture. In their work stock ideas, ranging from the Protestant Ascendancy ${ }^{6}$ to the shift in Irish writing from romance to realism in the wake of the civil war $^{7}$, have been exposed as so many de-historicized readings of Irish culture. If such investigations invite a reappraisal of terms used with regular insistence in Irish literary and cultural studies, then the concept of revival - a blanket term to describe a range of cultural activities in Ireland in the late nineteenth century - remains so popular and durable that its adequacy as a concept must be considered. When the G.A.A. claims to have revived Ireland's national pastimes, for instance, what have they revived and how comprehensive was that revival?

Most historians of the G.A.A. claim continuity between the activities of the association and Gaelic culture. David Greene prefaces his groundbreaking study of the association's politics with an account of hurling's place in the Gaelic poetry of the sixteenth century along with a description of the Statutes of Galway, 1529, which proscribed playing the game ${ }^{8}$. Likewise, Marcus de Búrca begins his survey of the association by citing provisions in the Brehon laws for compensation to a person harmed by a hurley ${ }^{9}$. In both these works, hurling is firmly situated at the center of Gaelic culture. Yet, accounts of the Irish pastimes just before and after the mid-nineteenth century famine in Ireland reveal that hurling was not necessarily the obvious pastime the G.A.A. might have wished to revive. When Sir William Wilde (father of Oscar) describes the Finglas Sports Day in his work

6. William McCormack, From Burke to Beckett: Ascendancy, Tradition, and Betrayal in Literary History, Cork, Cork University Press, 1994, p. 83.

7. Eamonn Hughes, "Leavis and Ireland: An Adequate Criticism?" Text and Context (1988), p. 126.

8. David Greene, The Gaelic Athletic Association and Nationalist Politics: 1884-1924, Dublin, Gill and Macmillan, 1987 , p. 74-76.

9. Marcus de Búrca, The Story of the G.A.A. to 1990, Dublin, Wolfhound Press, 1990, p. 2. 
Irish Popular Superstitions (1849), in a program that includes foot-racing, pig chasing, hopping and leaping, wrestling, sack races and blind man's buff, hurling is conspicuous by its absence ${ }^{10}$. When Archbishop Croke praises the revival of hurling in his letter offering patronage to the Association in 1884, this team sport is only one among the many other Irish pastimes, which includes leap-frog, handygrips, wrestling, snap-apple, and bonfire night, that he wishes to see encouraged.

While hurling does not feature in the description of the Finglas Sports Day, Wilde does cite the game in a discussion of a number of fairs whose demise the book is documenting. Donnybrook Fair was perhaps the most famous of these gatherings, a 15-day festival of great economic and social significance in the Irish calendar until the mid-nineteenth century. The proscription of these festivals by the civic authorities, encouraged by the Catholic clergy and the temperance movement, followed similar patterns in England where factory employers, land owners, evangelical preachers, and state officials formed an uneasy alliance to monitor, control, and reshape popular leisure activities ${ }^{11}$. The replacement of these Irish festivals by monthly one-day events are part of a larger restructuring of leisure time across the British Isles as a whole in the interest of the increasing rationalization of work and leisure time. When we speak of the revival of Gaelic games then, we should remember those other pastimes less amenable to the processes of modernization that the association chose to ignore. The codified version of hurling is played within a discrete period of time and can be watched in a space that can be readily commodified. Certainly, the codification and promotion of native games by Michael Cusack and the G.A.A. provided recreation for a population whose numbers and morale had been decimated by famine and emigration, yet these sports succeed because they accommodate the cultural expectations and economic realities of late nineteenth-century Ireland. Rather than see the G.A.A. as simply reviving ancient Gaelic pastimes, I suggest that the games promoted by the organization should be considered in the context of those other Irish pastimes they ousted, the economy into which they were inserted, and the contemporaneous sporting models they emulated.

Indeed, what is most striking about the early history of the G.A.A. is the essential modernity of the organization. The association took initial form in an exchange of letters between Michael Cusack and the internationally renowned Irish athlete Maurice Davin. Writing to Davin on October $11^{\text {th }}, 1884$, Cusack launched an attack on Irish sporting bodies affiliated with England because they "did not originate with those who ever had any sympathy with Ireland or the Irish

10. William Wilde, Irish Popular Superstitions, Dublin, Irish Academic Press, 1979, p. 62-63.

11. John Hargreaves, Sports, Power, and Culture, New York, St. Martin's Press, 1986, p. 21. 
people" concluding that the "vast majority of the best athletes in Ireland [were] Nationalists ${ }^{12}$ ". As Mandle points out, Cusack's letter was more a "blistering attack on Anglicization than a celebration of Irish sport ${ }^{13}$ ".

In this sense, Cusack's letter bears comparison to Douglas Hyde's seminal essay "The Necessity of De-Anglicizing Ireland." Hyde's essay is not merely an attack on the products of English culture he sees as displacing Gaelic or Celtic art and customs - the music halls, the penny dreadfuls and so on - it is also an assault on the material base, "the land of wealth and factories" that have produced and disseminated them. As J. J. Lee notes, Hyde equated modernization with anglicization. Yet as Lee suggests, many of the developments that Hyde describes as part of the process of anglicization - the proliferation of government boards, the diffusion of popular literature, the growth of mass consumption - could be witnessed more or less simultaneously in all European countries ${ }^{14}$.

Indeed, it is Hyde's own nostalgia that can be most readily identified as a product of England. Hyde's sentiments resonate with the arguments of the English arts and crafts movement and such representative figures as William Morris, Eglantyne Jebb, and Mary Fraser Tytler. Hyde's response to industrialization owes such an obvious debt to English critiques of industrialism that George Bernard Shaw irreverently describes his language movement in the Preface to John Bull's Other Island as "a quaint little offshoot of English pre-Raphaelitism ${ }^{15}$ ".

This is not to suggest that Hyde's fear of the effects of modernization on Gaelic language and culture were unfounded. The development of steam-driven print technology, the growth of popular journalism, and the monopolization of both by Anglophone culture in Ireland exerted enormous pressure on Gaelicspeaking communities. If, as Benedict Anderson has argued, print lays the basis for the imagined community of the nation, it also privileges the dominant print language, which in the case of Ireland was English ${ }^{16}$.

In stark contrast to Hyde, who rightfully feared the effects of the modernization on the Irish language, Cusack and his associates figured out ways in which the new communication technologies could be harnessed to promote Irish sport. We need only consider for a moment the Irish railway network to get a sense of how new technologies affected the Irish language and Irish sport differently. On returning from England, D.P. Moran observed that the Irish-speaking areas

12. Pagraig, Griffin. The Politics of Irish Athletics: 1850-1990, Ballinamore, Marathon Publications, 1990, p. 10.

13. W. F. Mandle, The Gaelic Athletic Association and Irish Nationalist Politics: 1884-1924, London, Christopher Hicks, 1987, p. 4.

14. J.J. Lee, The Modernisation of Irish Society: 1848-1918, Dublin, Gill and Macmillan, 1973, p. 140.

15. George Bernard Shaw, "Preface for Politicians," John Bull's Other Island, London, Constable and Company, 1927 , p. 35.

16. Benedict Anderson, Imagined Communities, London, Verso, 1983, p. 47. 
of North Cork began where the railway ended and ended where it resumed ${ }^{17}$. If Moran could lament the deleterious effects of the railway on the Gaelic language, the G.A.A. used the new transport system to its advantage. As early as 1888, special trains were laid on by the railway to bring people to the first Leinster final. ${ }^{18}$ Indeed, the recognition by both the association and the railway of their interdependence led to some friction between the two parties. The G.A.A. postponed the 1910 All-Ireland final because it was in dispute with the railway over the price of train tickets from Kerry to Dublin ${ }^{19}$. Ultimately, the mutually beneficial nature of the relationship was acknowledged by the introduction of the interprovincial Railway Cup played at venues accessible by rail and first sponsored by the Great Southern Railway in $1927^{20}$.

If an expanding Anglophone print culture threatened the Irish language, Cusack proved a master at exploiting mass communications for the benefit of Irish sport. After the G.A.A.'s founding meeting in Thurles in October 1884, the organization, engaged in its first controversy by banning all athletes from competing at a G.A.A. event who had competed in any rival athletic meetings, had an opportunity to demonstrate its acumen for media promotion. The first athletic meeting of the Irish Amateur Athletic Association, founded to protest the G.A.A.'s ban, was a complete failure, because of the blanket advertisement for and attendance of Cusack's rival event ${ }^{21}$. The G.A.A. has repeatedly shown its willingness and ability to appropriate the newest developments in the culture industry. Luke Gibbons has looked at the relationship between radio and Gaelic games, arguing that "far from passively relaying the activities of a thriving sporting body to an already captive audience, both radio and press contributed substantially to creating a nationwide audience for Gaelic games ${ }^{22}$ ". Here then, we have a cultural body promoting Gaelic culture, which is willing to use the latest developments in communication technologies to promote its cause, even when these developments were undermining the Gaelic language.

Thus, if we want to better understand the particular form Gaelic games took in late nineteenth-century Ireland, we may want to abandon the paradigm of revival and follow W. F. Mandle's lead in reading the foundation of the G.A.A. as part of the larger emergence of organized amateur sport in the latter half of the nineteenth

17. Patrick Maume, D.P. Moran, Dundalk, Dundalgan Press, 1995, p. 10.

18. Eoghan Corry, Catch and Kick: Great Moments of Gaelic Football, 1880-1980, Dublin, Poolbeg, 1989, p. 30.

19. Ibid., p. 33.

20. Marcus de Búrca, The Story of the G.A.A. to 1990, Dublin, Wolfhound, 1990, p. 180.

21. W. F. Mandle, The Gaelic Athletic Association and Irish Nationalist Politics: 1884-1924, London, Christopher Hicks, 1987, p. 23.

22. Luke Gibbons, Transformations in Irish Culture, Notre Dame Press, 1996, p. 73. 
century in Britain at large. After all, as late as 1882, Michael Cusack, the G.A.A.'s founder, had been writing that cricket was the best game for Irish lads to play ${ }^{23}$.

In England, the codification of team sports was pioneered by the public schools. By 1864, the public schools commission noted that the most important pupils at Eton were not the best scholars but the members of the rowing team. As Bruce Haley notes, at Harrow, the cricket eleven and not graduating seniors were allowed dress privileges ${ }^{24}$. Codified team sports in England provided a space where the emerging middle-class and the aristocracy could identify themselves as class allies to the exclusion of the working class. Indeed, the proscription of popular pastimes in the British Isles as a whole and their replacement by amateur sports may mark the most significant extension of middle-class dominance from the economic field into areas of culture in the mid to latter part of the nineteenth century ${ }^{25}$.

Contemporary schoolboy literature played an important role in promoting team sport and articulating the ideological functions of these games. Thomas Hughes's evocation of Rugby in Tom Brown's Schooldays has fixed the image of the school as one that used sport to develop the young English gentleman. More than any other writer, Hughes is responsible for putting the muscle into the muscular Christianity that increasingly began to dominate the thinking of the English middle-classes from the mid to latter half of the century. Although the accuracy of Hughes's portrait of the school's principal Thomas Arnold has been contested, not least by the headmaster's son Matthew, there can be little doubt that Hughes's vision of Rugby was enthusiastically emulated in schools as well as in fiction in the wake of the book's publication. Increasingly sport, rather than schoolwork, was seen as the means of developing the character of young gentlemen. "The object of all schools is not to ram Latin and Greek into boys," declares Tom, "but to make them good English boys, good future citizens; and by far the most important part of that work must be done, or not done, out of school hours ${ }^{26}$."

Football is the first school activity that Tom encounters on arriving at Rugby. Having played a version of the game in his village all his life, Tom wants to participate but his new friend East warns him that he will be a month learning the rules of this school variety and that it's "no joke playing-up in a match" ${ }^{27}$. Following his friend's advice, Tom is content to watch his team, representing the boarders, beat the day-school team. In the celebrations that follow, Pater Brooke,

23. W. F. Mandle, The Gaelic Athletic Association and Irish Nationalist Politics: 1884-1924, London, Christopher Hicks, 1987, p. 3.

24. Bruce Haley, The Healthy Body and Victorian Culture, Harvard University Press, 1978, p. 164.

25. John Hargreaves, Sports, Power, and Culture, New York, St. Martin's Press, 1986, p. 7.

26. Thomas Hughes, Tom Brown's School-Days, Macmillan and Co, 1868, p. 59.

27. Ibid., p. 92. 
the captain of the boarders' team, addresses his cohort one final time before leaving for university. Downplaying his own contribution to the victory, Brooke puts it down to team-spirit: "It's because we've more reliance on one another, more of a house feeling, more fellowship than the School can have. Each of us knows and can depend on his next-hand man better - that's why we beat 'em today. We've union, they've division - there's the secret ${ }^{28}$."

While Tom Brown's School Days highlights the role of sport in forming bonds between the traditional aristocracy and the professional middle classes, the novel also shows how sport cultivates the esprit de corps and martial discipline necessary for young Britons to defend the empire. The boarders' victory celebrations highlight the close association of sport, patriotism, and militarism. The victorious schoolboys sing patriotic numbers commemorating Britain's military exploits across the sea including "The British Grenadiers," "The Siege of Seringapatam" and "The Chesapeake and Shannon" and conclude proceedings with a prolonged performance of "God Save the King ${ }^{29 "}$.

The narrative arc of Tom Brown's School Days neatly allegorizes the alliance of the aristocracy and the middle-class as moral and military guardians of Britain's empire. Tom, the son of a junior barrister, is the first in his family to attend public school. The book charts his growing friendship with East, a member of the aristocracy, who initiates Tom into the world of Rugby College. The book closes as Tom leaves for Oxford and his friend East joins his regiment in India where Tom is confident he will make a capital officer, as "no fellow could handle boys better, and I suppose soldiers are very like boys ${ }^{30}$ ". Tom and East's friendship and their respective journeys to Oxford and the colonies suggest that an emergent professional middle class can harmoniously cooperate with its aristocratic brethren to govern at home and abroad in Britain's expanding empire. In Tom Brown's Schooldays, we see the beginnings of a shift in public-school literature from preaching ethics to promoting team games and martial virtues. Tom's view of life is a curious conflation of rugby match and military campaign: life is "a battle-field ordained from of old, where there are no spectators, but the youngest must take their side, and the stakes are life and death ${ }^{31}$."

As the century drew to a close, literature about sport in Britain focused more and more on this martial aspect of team games, stressing the role athleticism could play in defending the empire and training officials to administer it. J. E. C. Welldon, the headmaster of Harrow, isolated those qualities that the English schoolboy learned on the playing fields: pluck, energy, perseverance, self-control 
and esprit de corps when accounting for Britain's dominance over its European rivals, concluding that "England has owed her sovereignty to her sports 22 ". Cecil Rhodes, the paragon of British imperialism, stipulated that his scholarship to the Oxbridge universities only be available to those who commanded prowess in manly outdoor games ${ }^{33}$.

Rudyard Kipling's "The Islanders," often quoted as an expression of contempt for the culture of "flanneled fools at the wicket" and "the muddied oafs at the goals," only underscores how conflated the games of sport and the sport of empire had become. If Kipling locates indolence at the crease, he suggests discipline will be rediscovered there as well:

Each man born in the Island entered at youth to the game

As it were almost cricket, not to be mastered in haste

But after trial and labour, by temperance, living chaste.

As it were almost cricket - as it were even your play,

Weighed and pondered and worshipped, and practiced day and day.

So ye shall bide sure-guarded when the restless lightnings wake

In the womb of the blotting war-cloud, and the pallid nations quake ${ }^{34}$.

Henry Newbolt's hugely popular poem "Vitae Lampada" suggests that the lifelessons of cricket can come to the aid of the Empire. Concluding with a tableau of a daring defense by a young British soldier of a colonial garrison, a young officer, finding "the Gatling jammed and the Colonel dead", draws on all the resources he has acquired batting out a difficult innings back in England to rally his men ${ }^{35}$. The poem shares the young Tom Brown's conviction that soldiers are indeed like children and, in the end, what distinguishes the British abroad is their willingness to "play up Lads! play up and play the game!"

Training the bodies and disciplining the minds of the future officers of empire were not the only ways in which sport was seen as contributing to the work of empire. Commentators also saw sports as a means of nurturing cultural bonds between those in the metropolitan center and those in British dominions. J. A. Mangan's study of sport and empire shows how Victorians conceived of sport as the "social cement of empire", a means of holding the empire together not through the force of arms, but through bonds of brotherhood ${ }^{36}$. In the case of Ireland, Alan Bairner suggests that a large section of the middle-class community

32. Quoted in Allen Guttmann, Games and Empires: Modern Sports and Cultural Imperialism, Columbia University Press, 1985, p. 5.

33. Derek Birley. Land of Sport and Glory: Sport and British Society, 1887-1910, Manchester, UP, 1995, p. 245.

34. Rudyard Kipling, "The Islanders," The Collected Verse of Rudyard Kipling. New York, Doubleday, Page \& Company, 1907, lines 45-51.

35. Henry Newbolt, "Vitae Lampada," Poems, Old and New, London, John Murray, 1913, line 11.

36. J. A. Mangan, The Cultural Bond: Sports. Empire and Society, London, Frank Casts, 1992, p. 4. 
would have viewed English games less as a cultural importation than as a natural inheritance, confirming Ireland's intimate ties to the mainland ${ }^{37}$. Rugby was probably first introduced into Ireland by college students who had attended public school in England and then returned home to complete their studies in an Irish university. The foundation of the Trinity Rugby Club in 1854 gives the club a substantial claim to be the oldest in continuous existence ${ }^{38}$. Bairner notes that the first honorary secretary of the club, Robert Henry Scott, a Dubliner, had attended school at Rugby, Hughes's Alma Mater ${ }^{39}$.

The introduction of cricket and rugby into the secondary schools' curricula quickly followed. By the 1870 's, for instance, rugby was well established in Clongowes. Joyce's opening description of Clongowes in A Portrait of the Artist makes an interesting comparison with Hughes's of Rugby. As in Tom Brown's School-days, Stephen's first impression of school is of boys swarming around a rugby ball ${ }^{40}$. Stephen is immediately set off from the rest of the boys by his lack of interest in physical pursuits. But the pervasive culture of teams sports is repeatedly invoked. As the weather improves, cricket replaces rugby ${ }^{41}$. Even Stephen, uninterested in sports in general, wears a cricket cap as a young student ${ }^{42}$. On visiting Queen's College, Cork with his father, Stephen is passed by a team of cricketers, "agile young men in white flannels and blazers, one of them carrying a long green cricket bag ${ }^{43}$ ". As we will see, this fleeting image of cricket in college will contrast sharply with the National University in Dublin by the time Stephen attends.

To account for the extension of British sports and their ethos from the universities into Irish secondary schools, we have to look, in part, to the zeal of the headmaster. J. A. Mangan suggests that headmasters acted the role of Gramsci's intellectuals, articulating and promoting the imperial values that the team game embodied $^{44}$. It is appropriate then, that Stephen Dedalus's tense exchange on Irish history with Deasy, the unionist headmaster of the school where he teaches, occurs before the backdrop of the playing fields. Nor is it incidental that the students under Deasy's care are playing hockey. As Birley points out, hockey in Ireland was "a small but significant emblem of ascendancy, smart young Protes-

37. Alan Bairner, "Ireland, Sport and Empire," An Irish Empire? Aspects of Ireland and The British Empire, Ed. Keith Jeffrey, Manchester, University Press, 1996, p. 60.

38. See Trevor West, The Bold Collegians: The Development of Sport in Trinity College. Dublin, The Lilliput Press, 1991.

39. Alan Bairner, "Ireland, Sport and Empire," p. 62.

40. James Joyce, A Portrait of the Artist as a Young Man, Hertfordshire, Wordsworth Classic, 1992, p. 4.

41. Ibid., p. 30.

42. Ibid., p. 70.

43. Ibid., p. 68-69.

44. J. G. Mangan, The Games Ethic and Imperialism: Aspects of the Diffusion of an Ideal, Harmondshire, Penguin, 1986, p. 22. 
tant males [took up] hockey rather than hurling ${ }^{45}$ ". The school's choice of sport promotes as well as reflects Deasy's unionist sympathies.

Stephen has been listening to Deasy's account of events in Ireland's recent history. Deasy's narrative appropriates a number of nationalist campaigns within his own triumphalist unionism. Stephen's interjections are an attempt to expose the partisan nature of Deasy's account, which reads the history of unionist victories as a kind of manifest destiny:

- History, Stephen said, is a nightmare from which I am trying to awake.

From the playfield the boys raised a shout. A whirring whistle: goal.

- The ways of the Creator are not our ways, Mr Deasy said. All human

history moves towards one great goal, the manifestation of God.

Stephen jerked his thumb towards the window, saying:

- That is God.

Hooray! Ay! whrrwhee!

- What? Mr Deasy asked.

- A shout in the street, Stephen answered, shrugging his shoulders ${ }^{46}$.

The goal on the hockey pitch that prompts the headmaster's assertion that all human history moves "toward one great goal, the manifestation of God" betrays Deasy's conviction that history is a kind of game in which those who win are right. Despite Stephen's non-committal appeal to the quotidian "shout in the sheet," the howls of celebration emanating from the hockey field to which he is actually referring suggest that the manifestation of God may be no more than the cries of the victor. Indeed, we can read Stephen's misattribution as a deliberate ploy to reveal that a cultural imposition (a game of hockey) can be so thorough that it has the appearance of everyday reality (a shout in the street). When Deasy reappears in Circe, trailing the field in a horserace and jeered on by the disappointed Orange lodges, Joyce has him comically brandishing his preferred symbol of Union, the hockey stick ${ }^{47}$.

Whereas Stephen's exchange with Deasy offers a pointed, if oblique, commentary on the role of sport in Irish schools from the perspective of the educators, Frank O'Connor's short story, "The Idealist", registers the impact of the culture of sport from the standpoint of a student. Delaney, the young narrator in O'Connor's story, is an avid reader of English school-boy fiction and adopts the values and speech of the English school-boys of whom he reads. He admires rugby and cricket because he believes they nurture the virtues of loyalty, pluck,

45. Derek Birley, Land of Sport and Glory: Sport and British Society, 1887-1910, Manchester, University Press, 1995 , p. 95.

46. James Joyce, Ulysses, New York, Vintage Books, 1986, p 28: 377-386.

47. Ibid., p. 468: 3988-3989. 
and honesty. Ventriloquizing the speech of a Tom Brown, Delaney laments that his school has "no team, so a fellow, no matter how hard he worked, could ever play for the school ${ }^{48}$ ". The story highlights the tension between the narrator's breathless admiration for English games and their increasing identification by Irish nationalists as garrison sports:

I worked hard at the football and cricket, though of course we never had a proper football and the cricket we played was with a hurley stick against a wicket chalked on some wall. The officers in the barrack played proper cricket, and on summer evenings I used to go and watch them, like one of the souls in Purgatory watching the joys of Paradise ${ }^{49}$.

While signaling that Delaney has co-conspirators in his plot to retool the camans of Ireland to play an English game, the passage clearly marks the status of football and cricket as part of the culture of the occupiers. O'Connor also suggests that the narrator's capacity to reinvent himself is limited. If Delaney yearns to sup on the pleasures of an English paradise, his misery as "one of the souls in Purgatory" has a distinctly Irish flavor. As the story progresses, O'Connor shifts the story's focus from the sports themselves to the ideological role played by schoolboy fiction in packaging these games as storehouses of English values. Delaney's efforts to emulate the life-style and values of the English school-boy lead to an open confrontation with his teacher, who tears his latest schoolboy fiction in half labeling it "[d]irty, filthy, English rubbish ${ }^{50 " . ~}$

\section{III}

The schoolmaster's suspicion of this “filthy, English rubbish” in O'Connor's story was not wholly unfounded. The celebration of team games as an expression of England's national character often coexisted with a conviction that the "native Irish" were incapable of governing their own affairs. While Newbolt's Vitae Lampada celebrates Britain's imperial history and the masculine triumphs of the young English player who "led the line that broke the foe" and the military officer, who with the "voice of a schoolboy rallies the ranks," his poem, "Ireland, Ireland," reduces Irish history to a dishonoring of a helpless feminized nation:

Long ago the anguish took thee,

Ireland, Ireland, green and fair,

Spoilers strong in darkness took thee

48. Frank O’Connor, “The Idealist," Daydreams and Other Stories, London, Pan Books, 1973, p. 10.

49. Ibid.

50. Ibid., p. 15. 
Broke thy heart and left thee there ${ }^{51}$.

Newbolt's recasting of Ireland's turbulent history as a Victorian melodrama with Ireland playing the role of a wronged and heartbroken damsel-in-distress exemplifies what George Watson identifies as a key feature of late nineteenthcentury Celticism: the conviction that change is never generated from within the passive Celtic world but is always imposed from without ${ }^{52}$.

As English team games and the literature that promoted their virtues became a venue for commentators like Newbolt to express their conviction that the English possessed the manly discipline needed to govern an Empire while representing the Irish as helpless victims of history, Irish nationalists seized on sport and its literary representation to engage with and refute these attitudes. The early efforts of nationalists to co-opt sport and its literature to their ends are not without ironies, however, caught as they are in a parasitic relation with the British forms they mimic as much as criticize.

Pádraig Pearse's The Murder Machine is a blistering attack on the imposition of English educational methods and values on Irish schools, calling for the freedom of Irish educators to create their own curricula. At the same time, Pearse's text rehearses many of those attitudes to sport propagated in England. Pearse states that schools should "care for the body as well as the mind" and that an ideal school would encourage "nobly-ordered games" for their "moral discipline" and their "physical hardening 53 ". In this sense, Pearse draws as much from the fields of Eton as he does from the trials of the Fianna. Making the martial values encoded in codified sport even more explicit, Hyde's "The Necessity of De-Anglicizing Ireland" praises the "brave and patriotic men of the G.A.A." who have developed the "physique of youth" and taught young Irishmen "self-restraint" and "how to obey their captains ${ }^{54 "}$ ".

The conflation of sport and war in the imperialist poetry of Newbolt and Kipling, is replicated in the nationalist verse of the period. As loyalists promoted British sport to affirm Ireland's place within the Union, nationalists began to adapt its militaristic rhetoric for nationalist purposes. Reverend James B. Dollard sees in the figure of the hurler the reincarnation of Ireland's ancient warrior caste:

Upon his native sward the Hurler stands

To play the ancient pastime of the Gael

And all the heroes famed of Innisfail

51. Henry Newbolt, "Ireland, Ireland," Poems, Old and New, London, John Murray, 1913, lines 5-8.

52. George Watson, "Celticism and the Annulment of History", Celticism. Ed. Terence Brown, Rodolpi, Amsterdam, 1996, p. 211.

53. P.H. Pearse "The Murder Machine", The Murder Machine and Other Essays, Cork, Mercer Press, 1976, p. 27.

54. Douglas Hyde, “The Necessity for De-Anglicizing Ireland," Language, Lore and Lyrics, Ed. Brendan O'Consaisc, Blackrock, Irish Academic Press, 1986, p. 168. 
Are typified in him $^{55}$.

Brian na Banban represents the Gaelic athletes as future soldiers for Irish freedom:

On Irish Fields when heroes died,

And foemen thronged on every side,

Our leaders' joy - their hope and pride

Were gleaming pikes - and Hurling men!

And if God wills that war's red train

Shall sweep once more o'er hill and plain

Our land shall call - and not in vain -

For fighting lines of Hurling men ${ }^{56}$.

Joyce quickly identified these militaristic undercurrents, attacking the association's militarism in Stephen Hero and A Portrait of the Artist. It is noteworthy that by the time Stephen reaches university, Irish games like handball and hurling are the sports in which his companions are engaged, indicating the emergence of the G.A.A. as a major cultural focus on Irish campuses. Both representatives of nationalism in the novels, Madden and Davin respectively, are committed G.A.A. players. Such a portrait would seem to confirm John Hutchinson's claims that the G.A.A. is chiefly responsible for the revival of student activism at the National University, providing a rallying point for the Catholic intelligentsia ${ }^{57}$. In Stephen Hero, Madden, captain of a hurling team, reports regularly to Michael Cusack on his school-fellows' "muscular condition ${ }^{58}$ ". In one exchange, Stephen sarcastically asks Madden if the hurling matches are preparation for the great event. Asked by Stephen about the camans, Madden replies that they are to "raise the physique of the country"5". In A Portrait, Stephen suggests that Davin tell him when they are having their "next rebellion with hurleysticks" so that he can offer them an "indispensable informer" In Stephen Hero, Joyce has Stephen play a game of handball with Cranly, which he loses even though he has been given a seven-point handicap ${ }^{61}$. Joyce's excision of Stephen's game of handball from A Portrait ensures that the hero's aversion to sport for either union or nation, first signalled in his representation of the young Stephen's indifference to rugby at Clongowes, is underscored.

55. James B. Dollard, “The Hurler”, Irish Lyrics and Ballads, Toronto, 1917, lines 1-4.

56. Brian Na Banban [Brian O' Higgins], "Ireland's Hurling Men”, The Voice of Banba, Dublin, 1907, lines 22-29.

57. John Hutchinson, The Dynamics of Cultural Nationalism: The Gaelic Revival and the Creation of the Irish Nation State, London, Allen and Unwin, 1987, p. 161.

58. James Joyce, Stephen Hero, Ed. Theodore Spencer, London, Jonathan Cape, 1956, p. 66.

59. Ibid., p. 67.

60. Joyce, Portrait, p. 156.

61. Joyce, Stephen Hero, p. 120. 
While the G.A.A. emulated the jingoism of English sporting bodies by wearing its nationalism very much on its green sleeves, it initially rejected the ideology of amateurism promoted by English sports because it excluded the working class. Michael Cusack repeatedly criticized Irish athleticism because its definition of amateurism debarred labourers, tradesmen, artisans, and even policemen and soldiers from participating in sport ${ }^{62}$. Despite the G.A.A.'s claims of inclusivity, however, a series of policy decisions early on clearly delineated the social and geographical lines along which the association's nationalism would run. Specifically, the set of bans introduced by the G.A.A. over the course of its first ten years had the inadvertent effect of alienating larger and larger sections of the urban working class.

The bans fell under three basic categories: the boycott rule, which ordered G.A.A. members to boycott all events organized under auspices of English sporting foundations; the police rule, which banned all security forces; and the foreign games rule, which expelled all members playing or watching foreign games. The history of these bans is complex. Often they were introduced for purely political purposes. The first ban on the Royal Irish Constabulary was introduced in 1887 by a National convention controlled by the I.R.B. and led to the resignation of Maurice Davin ${ }^{63}$. They were often removed if it was thought practical. At one stage in the 1890s, the G.A.A., starved of membership, removed its foreign games ban, cooperated with the I.A.A.A., allowed policemen to play, and military bands to entertain the crowds ${ }^{64}$. At its most stringent, however, the police ban extended to all British government employees including postal workers, teachers, and civil servants, soldiers, sailors, police, and militia.

This is not to suggest that Cusack's avowal of sympathy for the artisan, tradesman, policeman, the soldier, and the urban working class was disingenuous or that there was any lack of good will on the part of the association towards urban communities. The playing of games on a Sunday, for instance, although offensive to the sabbatarianism of many Irish Protestants, suited many workers who worked a 6-day week. The G.A.A. also supported the workers in the great lock-out in Dublin in 1913, attested by the letter of a young enthusiast, Sean O'Casey, to The Irish Worker: "Evidences are everywhere manifesting themselves of the Gael's determination to stand by the workers in their magnificent fight to vindicate the liberties of man. The G.A.A. has nobly taken its stand with the workers ${ }^{65}$." The National Convention of 1919 that voted to amend the ban which suspended all civil servants from the association for taking the oath of allegiance, also voted to

\footnotetext{
62. Pagraig Griffin, The Politics of Irish Athletics: 1850-1990, Ballinamore, Marathon Publications, 1990, p. 10.

63. See W. F. Mandle, The Gaelic Athletic Association and Irish Nationalist Politics. 1884-1924, p. 38.

64. Ibid., p. 111.

65. Sean O'Casey, The Letters of Sean O'Casey: 1910-1941, London, Cassell, 1975, p. 31.
} 
support the Limerick strike relief fund with money and charity games, a tacit endorsement of the "Limerick Soviet". Yet these gestures, however well meaning, did not slow the erosion of the organization's base in the towns and cities of Ireland (and among Irish communities in the cities of England and Scotland) as a result of the ban.

The organization's bans disproportionately affected urban working-class communities. O'Casey's Pictures in the Hallway confirms that his initial enthusiasm for the organization was short-lived. O'Casey's semi-autobiographical work offers a more tempered appraisal of the association. The book opens with a moving description of the arrival of Parnell's coffin back in Dublin. O'Casey's description of the funeral cortege is rich in detail, vividly described through the eyes of a young child:

No damask, silk, or brocade threw beauty into the moving, silent throng; no rich banners, heavy with heraldry hatched a thousand years ago; not a single jewelled order flashed from a single breast, rising and falling with the dark rolling drumbeat of the Dead March; no bishops, posing as sorrow and salvation, in purple and gold vestments, marched with the mourning people; many green banners, shrouded with crape, flapped clumsily in the wet wind, touched tenderly here and there, with the flag of the United States and the flag of France, floated over the heads of the stricken host, retreating with its dead to the place that would now be his home forever ${ }^{66}$.

What is missing here, of course, is the the cortege of 2,000 G.A.A. men, who six abreast accompanied Parnell's coffin from St. Stephen's Green to City-hall, carrying on their shoulders their camans draped in black ${ }^{67}$. By O'Casey's omission, Parnell becomes a figure deserted by all the official organs of nationalism in Ireland, mourned only by the ordinary working people of Dublin.

O'Casey came to resent how the policies of the G.A.A. excluded his family in three distinct ways: as Protestants, as workers, and as members of the army. The divided loyalties of the many parties affected by the ban are touched on in the "Cat N Cage" episode of his book. Johnny's brother Tom, a member of the Royal Dublin Fusiliers, is on leave. On the way to their local bar, Johnny, Tom and an army companion are passed by several jaunting-cars of hurlers wearing green jerseys, waving hurleys and singing a song mocking Irish recruits. A policeman, who has been watching the scene, makes a sympathetic gesture of camaraderie with the soldiers but they ignore him, not wanting to be seen talking to

66. Sean O'Casey, Pictures in the Hallway, New York, Macmillan, 1949, p. 20.

67. See Mandle, Gaelic, p. 85. 
a policeman ${ }^{68}$. When the three finally arrive at their local, the hurlers are there, standing beside a pair of police officers. The hurlers continue to jeer Tom, who in reply derides their rural origins, dismissing them as "Bog-trotters" and "Hayfoot, strawfoot fusiliers ${ }^{69}$ ". An argument ensues between the hurlers and the two young soldiers over Parnell. Tom accuses the priesthood and the Irish people of sending Parnell to his grave. In a richly ironic turn of phrase, considering the G.A.A.'s historical role in Parnell's funeral, a hurler replies that "no hand here helped him into his coffin ${ }^{70}$ ". The passage ends with another hurler attacking the barman for insulting Parnell, Tom using a hurling club to strike one of the constables, and the soldiers and hurlers scattering together ${ }^{71}$. Tom suggests they steal a jaunting car to get away only to discover that the hurlers can't drive because they are city men and have never ridden a horse-and-carriage in their lives ${ }^{72}$. Tom takes the reins and the group escapes, soldiers and hurlers parting company with the salute "Parnell forever!" "An' Ireland too ${ }^{73 !}$ !" The episode figures the G.A.A. as a source of division between nationalists and members of the Dublin working class. When Johnny makes his first faltering steps into socialism and nationalism, the Gaelic League provides a more welcoming arena for reconciling his nationalist sympathies and his urban working-class origins.

Joyce explores the divided loyalties created by the ban in Stephen Hero. In his discussion with Madden about Gaelic sport, Stephen lists the parties effected by the ban - the armed forces, the civil services, and the police - asking Madden to explain why these professions are forbidden from partaking in Ireland's national pastimes. Stephen points out to Madden that "nearly ten of your friends are sons of police inspectors ${ }^{74}$."

Despite de Búrca's efforts to establish the organization's urban credentials by making much of the Association's 1904 relocation of its headquarters from Thurles to Dublin ${ }^{75}$, it is evident that the organization failed to establish a real constituency in the urban areas of Ireland. The fact that De Búrca's table of G.A.A. presidents boasts only one tradesman (out of the list of workers denied access to sport by the English bodies Cusack originally attacked) is a more telling index of urban involvement within the organization's hierarchy. It is to the countryside then that we must turn to explore the abiding influence of the G.A.A.

\footnotetext{
68. O'Casey, p. 74.

69. Ibid., p. 77.

70. Ibid., p. 82.

71. Ibid., p. 88.

72. Ibid., p. 89.

73. Ibid., p. 92.

74. Joyce, Stephen Hero, p. 68-69. Michael Cusack, the Association's founding father, had earned his living preparing civil servants and policemen for their professional examinations.

75. Marcus de Búrca, The Story of the G.A.A. to 1990, p. 93.
} 
How did the G.A.A. establish itself so quickly and firmly in rural Ireland? There are two possible answers. An intriguing explanation is offered by Tom Garvin's claim that the G.A.A.'s use of the parish acted as "a substitute for the old parish factions which had absorbed the energies of the young men in the pre-famine period ${ }^{76}$. In this reading, the association fills a political or pre-political void in post-famine Ireland. This places the early evolution of the body firmly in the tradition of secretsocieties like Ribbonism and Defenderism that persisted in defiance of the Catholic hierarchy. Garvin argues that the G.A.A. "absorbed much of the old secret society and factional tradition into itself ${ }^{77 "}$. There is evidence that in 1883 the supreme council of the Irish Republican Brotherhood had formed a sub-committee to devise ways of bringing a national athletic body into existence. By 1887, Dublin Castle would describe the association as a "most dangerous organization ${ }^{78 "}$. It is worth remembering that the G.A.A.'s support of Parnell after the divorce controversy was in open opposition to their Catholic patron, Archbishop Croke, who referred to him as "a moral leper", and that after Parnell's death, the association elected in his place not a constitutional politician but James Stephens, the founder of the Irish Republican Brotherhood ${ }^{79}$. Certainly, in A Portrait, Joyce associates the G.A.A. with paramilitary fenianism. Davin, the hurler in A Portrait, is rumoured a "young fenian" by Stephen's fellow-students ${ }^{80}$. On discovering that Davin has signed the petition for Universal Peace, Stephen mockingly repeats the paramilitary drills he has read in his friend's note-book: "Long pace, fianna! Right incline, fianna! Fianna, by numbers, salute, one, two ${ }^{81}$ !"

Yet, a more convincing explanation of the association's success in rural Ireland lies with the organization's alliance with the Catholic Church. Mandle argues that the introduction of the "one parish, one club" rule was a masterstroke, encouraging the Catholic Church to become involved and allowing the association work through the Church's social network ${ }^{82}$. The priests were also responsible for introducing the new sports of hurling and football into the Catholic national schools in the wake of the Powis commission ${ }^{83}$. Indeed, the fall off in support for the G.A.A. during its years of Fenian militancy represented a decisive victory for the Catholic Church in its struggle with republicanism for the control of the organization.

76. Thomas Garvin, The Evolution of Irish Nationalist Politics, Dublin, Gill and Macmillan, 1981, p. 65.

77. Ibid., p. 65.

78. W. F. Mandle, The Gaelic Athletic Association and Irish Nationalist Politics:1884-1924, p. 43.

79. See Conor Cruise O’Brien, States of Ireland, London, Hutchinson, 1972, p. 28-29.

80. Joyce, Portrait, p. 139.

81. Ibid., p. 155.

82. W. F. Mandle, "The Gaelic Athletic Association and Popular Culture, 1884-1924," Irish Culture and Nationalism. 1750-1950, Ed. Oliver MacDonagh, Dublin, Gill and Macmillan, 1983, p. 106.

83. See Mandle, Gaelic Athletic Association, p. 133. 
Whereas Joyce associates the G.A.A. with fenianism in $A$ Portrait, by the time he writes Ulysses he identifies the association as more Catholic than republican. In the "Cyclops" episode, Joe Hynes mentions that Nannan is going to ask a question in parliament about the commissioner of police forbidding Irish games in Phoenix Park. The ensuing discussion is related in a parody of a newspaper report on a local political debate. Speakers identify the importance of sport in developing the Irish race and the Citizen closes the proceedings with a stirring rendition of "A Nation Once Again ${ }^{84 "}$. The report ends with a list of the clergy present - a list of twentyfive Catholic priests - underscoring the sectarian flavor of the organization ${ }^{85}$.

Joyce and O'Casey's distrust of the G.A.A. never blinded them to the centrality of the movement to the development of Irish nationalism. Both writers clearly mark its role in molding the type of nationalism that would come to the fore in the coming decades. Yeats may well wonder if that play of his sent out certain men the English shot, but we can be certain that of the fifteen they executed in the wake of the Easter Rising, five were G.A.A. activists.

In the summer of 1924, a number of months after the official cessation of hostilities in its civil war, Ireland hosted the Tailteann Games, the largest public event in the history of the newly formed state. Attended by 140,000 spectators, boasting guest speakers ranging from Yeats to Chesterton, the event was Corkery's hurling match writ large. Organized by the G.A.A., the Games confirmed the central role of Irish sport in the shaping and expression of Irish identity.

When Corkery surveyed the crowd in Tipperary, he saw three great forces at work in the Irish national being: "the religious consciousness of the People, Irish Nationalism and the Land ${ }^{86}$." As Eamonn Hughes notes, Corkery has revised a formulation from his 1908 essay The Hidden Ireland, altering the last characteristic feature of Irish culture from "rebellion" to "the land ${ }^{87}$ ". From its status as a center of opposition to the British state, Irish culture must now assume a new role as bulwark of the rural status quo. Obviously, Corkery's triumvirate formulation excludes many constituencies that before and after independence would have considered themselves Irish. Yet, if the hurling crowd fails to represent the Irish nation, it perfectly embodies an official nationalism that was Catholic, exclusive, and rooted in the soil.

84. Joyce, Ulysses, p. 260: 900 and 260: 917.

85. Ibid., p. 260: 927-938.

86. Corkery, Synge and Anglo-Irish Literature, p. 19.

87. Eamonn Hughes, "It Seems History is to Blame: Ulysses and Cultural History," Ideas and Production, 1987: 6, p. 111. 